\title{
A description of two new species of coccidia (Apicomplexa: Eimeriidae) from African reptiles with nomenclatural corrections for two Caryospora and one Eimeria species from snakes
}

\author{
Peter Daszak ${ }^{1,2}$ and Stanley John Ball ${ }^{2}$ \\ ${ }^{1}$ Institute of Ecology, University of Georgia, Ecology Building, Athens, GA 30602-2403, USA; \\ ${ }^{2}$ School of Life Sciences, Kingston University, Kingston-upon-Thames, Surrey KT1 2EE, UK
}

Key words: Coccidia, Apicomplexa, Eimeriidae, Eimeria, Caryospora, Reptilia, Sauria, Serpentes, Gerrhosaurus, Chamaeleo, Dendroaspis, Python, Psammophis

\begin{abstract}
Two new species of coccidian parasites are described from African reptiles. Oocysts of Eimeria foulshami sp. n. from the plated lizard Gerrhosaurus major bottegoi Del Prato of Sudan are ellipsoidal, $24.1 \times 14.9(23-26.5 \times 14-17.8) \mu \mathrm{m}$ with a bilayered, colourless oocyst wall and lack polar granules. The ellipsoidal sporocysts average $8.6 \times 4.6(7-10.6 \times 4.4-7) \mu \mathrm{m}$ and possess a prominent, globular, sporocyst residuum. Oocysts of Caryospora regentensis sp. $\mathrm{n}$. from the green mamba Dendroaspis viridis Hallowell of Kenya are spherical to subspherical, $16.8 \times 16.4(16-17.6 \times 15-17.2) \mu \mathrm{m}$ with a bilayered oocyst wall and a single polar granule. The ellipsoidal sporocysts average $13.0 \times 10.3(10.2-14 \times 9.2-11) \mu \mathrm{m}$ and possess a Stieda and substieda body and a prominent globular sporocyst residuum. Oocysts of Caryospora legeri Hoare, 1933 are reported from a hissing sand snake, Psammophis sibilans sibilans L. from Nigeria, representing a new geographical record. The oocysts are slightly larger than the type, but otherwise identical. Caryospora psammophi Bray, 1960 and C. hermae Bray, 1960 from Psammophis sibilans phillipsi, oocysts of which are morphologically similar to and overlap in dimensions with $C$. legeri Hoare, 1933, are synonymised with the latter species. Eimeria samiae Iskander et Tadros, 1979 is emended to E. samyadeli to reflect the gender of the person the species was named after and because E. sami is preoccupied. In addition to these findings, Eimeria bohemi Modrý, Šlapeta et Koudela, 2000 and oocysts of an unidentified spherical Eimeria sp. are reported from Chamaeleo dilepis dilepis Leach from Cameroon.
\end{abstract}

The number of coccidia described from African reptiles is low in relation to the large size of the continent and diversity of reptile fauna. Most recent papers have concerned host species from outlying regions, such as North Africa (e.g. Amoudi 1989), Madagascar (e.g. Upton et al. 1990), Namibia (e.g. Upton et al. 1992) and Indian Ocean islands (e.g. Modrý et al. 1997). The current paper describes two new species of coccidia from reptiles of African regions south of the Sahara: Gerrhosaurus major Del Prato (Sauria: Cordylidae) and Dendroaspis viridis Hallowell (Serpentes: Elapidae). No coccidia have previously been reported from these species. There are no known coccidia from Gerrhosaurus spp. lizards or Dendroaspis spp. snakes. Only one eimerian has been reported from the family Cordylidae (Upton et al. 1993) and four caryosporans are known from elapid snakes (Cannon 1967, Matuschka 1982, Nandi 1985, Lainson et al. 1991).

\section{MATERIALS AND METHODS}

Faecal samples were collected from animals housed individually or in small groups of the same species at the Zoological Society of London (ZSL), Regent's Park, London, UK or at a dealer's premises. So as to eliminate the possibility that the coccidia found were from hosts other than the normal species infected in the wild, only animals which had been caught, held and imported individually or in groups of the same species from the same locality were used in this study. Faecal samples were placed in $2.5 \%$ potassium dichromate in which the oocysts sporulated. Oocysts were photographed and measurements (given here in $\mu \mathrm{m}$ ) were taken under oil using a Zeiss photomicroscope III fitted with an eyepiece micrometer. The oocysts observed were compared with those already reported from lizards of the Cordylidae (=Zonuridae) for Gerrhosaurus major and the Elapidae for Dendroaspis viridis.

\section{RESULTS}

APICOMPLEXA: E i m e r i i d a e

Eimeria foulshami sp. n.

Figs. 1, 4

Description: Oocysts cylindroidal, $24.1 \pm 1.3 \times 14.9 \pm$ $1.0(23-26.5 \times 14-17.8), \mathrm{n}=15$; shape index (SI, mean length/mean width) 1.62 . Wall bilayered, smooth and colourless, about 0.7 thick. Micropyle, oocyst residuum and polar granules absent. Sporocysts ellipsoidalcylindroidal, $8.6 \times 4.6(7-10.6 \times 4.4-7), \mathrm{n}=20$; SI $=$ 1.9 , with prominent sporocyst residuum, Stieda and substieda bodies absent and a single posterior residual body usually visible. 

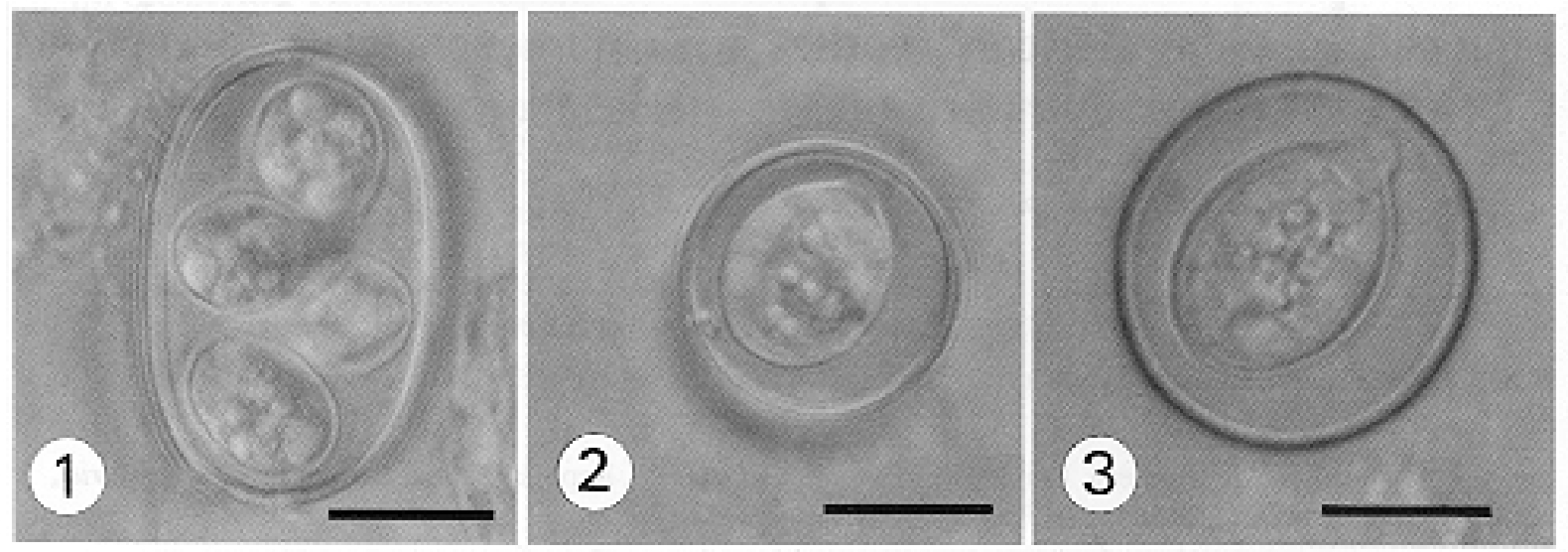

Figs. 1-3. Nomarski differential interference contrast photomicrographs of sporulated oocysts of coccidian parasites from African reptiles. Fig. 1. Type for Eimeria foulshami sp. n. from Gerrhosaurus major bottegoi. Fig. 2. Type for Caryospora regentensis sp. n. from Dendroaspis viridis. Fig. 3. Caryospora legeri from Psammophis sibilans sibilans. Scale bars $=10 \mu \mathrm{m}$.

T y p e h o s t: "Plated lizard" Gerrhosaurus major bottegoi Del Prato (Sauria: Cordylidae). The subspecific designation follows that of Broadley (1987). It was not possible to obtain permission to euthanise animals for deposition of a symbiotype.

T y p e 1 o c a 1 i t y : Near Loka, southern Sudan, $4^{\circ} 7^{\prime} 51^{\prime \prime}$ N, 31 9'36',E. Faecal sample collected one month after importation into the UK.

T y p e m a t e r i a 1: Phototype deposited at the Natural History Museum, London. The accession number for the holotype is 1999:12:3:4. The images will be digitised and kept in perpetuity as a computer file ("digitotype").

$\mathrm{S}$ i t e of i n fectio $\mathrm{n}$ : Unknown; oocysts found in faeces.

Pre v a l e n c e : $1 / 8$ (12.5\%) animals collected from various locations in Sudan and imported at different times were positive for E. foulshami.

Additional hosts and localities: None.

$\mathrm{Et} \mathrm{y} \mathrm{molog} \mathrm{y:} \mathrm{The} \mathrm{specific} \mathrm{name} \mathrm{is} \mathrm{given} \mathrm{for} \mathrm{Peter}$ Foulsham, who greatly assisted in collection of faecal samples from an extensive collection of reptiles over a three-year period.

\section{Caryospora regentensis $\mathrm{sp} . \mathrm{n}$.}

Figs. 2, 5

Description: Oocysts spherical to subspherical (predominantly spherical), $16.8 \pm 0.53 \times 16.4 \pm 0.72$ $(16-17.6 \times 15-17.2) \mathrm{n}=20 ; \mathrm{SI}=1.02$. Wall doublelayered, smooth and colourless, about 0.5 thick. Micropyle and oocyst residuum absent, single polar granule present. Sporocysts ovoidal, $13.0 \times 10.3(10.2-14.1 \times$ $9.3-11.1), \mathrm{n}=20$; SI 1.26. Cap-like Stieda body and globular, ellipsoidal substieda body present. Stieda and substieda bodies are roughly the same length and width. Prominent, large sporocyst residuum present, consisting of numerous (15-20) large globules compacted within the curvature of the sporozoites and filling up the sporocyst completely. A single posterior residual body is usually visible in the sporozoites.

$\mathrm{T}$ y $\mathrm{p}$ e h o s t : "Green mamba", Dendroaspis viridis Hallowell, 1844 (Serpentes: Elapidae). The host individual was an adult male, ZSL accession No. C190. The samples were collected 17 months after importation into the UK (arrival in UK: 28th April 1989, sample collected 9th October 1989). This individual was previously held at the National Museum of Kenya, Nairobi, Kenya for a short, but unknown period. Because this animal was part of a captive breeding programme, it was considered unethical to euthanise the individual for deposition of a symbiotype.

$\mathrm{T}$ y p e 1 o c a 1 i t y : Green mamba was captured at an unknown location in Kenya.

T y p e mate r i a 1: Phototypes deposited at the Natural History Museum, London. The holotype (accession number 1999:12:3:1) and two paratypes have been deposited (accession numbers 1999:12:3:2 and 1999:12:3:3). These will be digitised and kept in perpetuity in the form of computer files ("digitotypes").

$\mathrm{S}$ i t e of in fection: Unknown; oocysts found in faeces.

$\mathrm{P}$ r e v a 1 e n c e : $1 / 1$ individual harboured oocysts of $C$. regentensis.

Additional hosts and localities: None.

E t y m o lo g y : The specific name is given in honour of the Zoological Society of London, which has been located in Regent's Park, London since the society's founding in 1826. Through its zoological gardens and the Institute of Zoology, this learned society has conducted over 150 years of practical conservation work and scientific research. The name is derived from the addition of "-ensis" ("of the place") to a latinisation of the proper noun "Regent's" ("Regent"). 


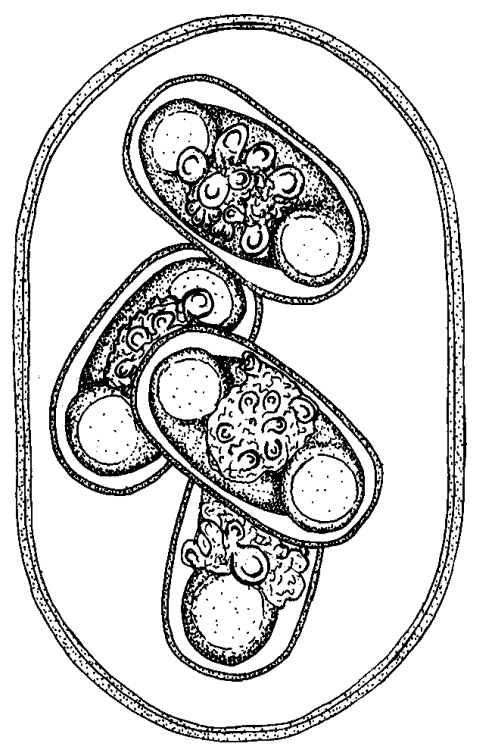

4

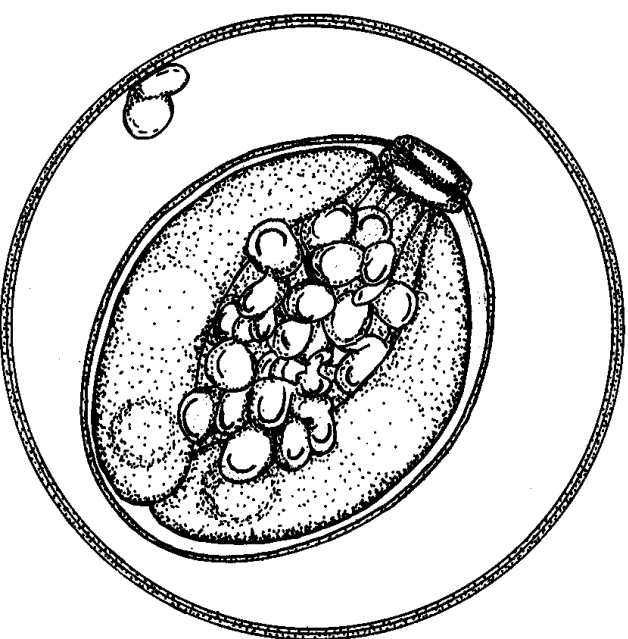

5

Figs. 4, 5. Composite line drawings of sporulated oocysts of coccidian parasites from African reptiles. Fig. 4. Eimeria foulshami sp. n. Fig. 5. Caryospora regentensis sp. n. Scale bars $=10 \mu \mathrm{m}$.

\section{Caryospora legeri Hoare, 1933}

Fig. 3

Description: Oocysts subspherical, $33.0 \pm 1.7 \times 29.3$ $\pm 1.3(29.8-36.0 \times 27-32.4) \mathrm{n}=100 ; \mathrm{SI}=1.13$. Micropyle, oocyst residuum and polar granule absent. Sporocyst ovoidal, $22.0 \pm 0.8 \times 13.1 \pm 0.8(20.8-23.4 \times$ 12.6-14.2) $\mathrm{n}=100$. Stieda and substieda bodies present, although substieda body difficult to distinguish in some oocysts. Substieda body slightly wider than Stieda body, but thinner. Granular sporocyst residuum present, consisting of a large elongate mass lying at the centre of the group of sporozoites and visible protruding between them.

H o s t: "Hissing sand snake", Psammophis sibilans sibilans L., 1758 (Serpentes: Colubridae).

L o c a 1 i t y : Sokoto, northwestern Nigeria, 1311'19' 'N, $5^{\circ} 17^{\prime} 24^{\prime}$ 'E. Sample collected at a dealer's premises two months after importation into the UK.

$\mathrm{S}$ i t e of in fecti o n: Unknown; oocysts found in faeces. Pre v a 1 e n c e : $1 / 1$ animal positive for oocysts.

\section{Other findings}

Examination of faecal samples from an individual Chamaeleo dilepis dilepis Leach, 1819 ("flap-necked chameleon") recently imported into the collection of the ZSL from Cameroon, West Africa, revealed large numbers of oocysts of Eimeria bohemi Modrý, Šlapeta et Koudela, 2000. These were cylindroidal $26.5 \pm 1.1 \times$ $17.0 \pm 0.63(25-27.5 \times 16.2-17.5), \mathrm{SI}=1.56$, with ellipsoidal sporocysts, $9.5 \times 6.0(8.8-10 \times 5-7.5), \mathrm{SI}=1.6$.
They differed only slightly from the type description, in oocyst and sporocyst shape indices. The same individual revealed very few oocysts of an unidentified spherical Eimeria species. The latter were spherical 24 $\times 24(24-24.2 \times 24-24.2), \mathrm{SI}=1.0, \mathrm{n}=3$. Micropyle, oocyst residuum and polar granules absent. Sporocysts ellipsoidal, $10.6 \times 8.8, \mathrm{SI}=1.21, \mathrm{n}=3$.

\section{DISCUSSION}

Eimeria foulshami. Paperna and Landsberg (1989) proposed two new generic names for eimerian coccidia of reptiles based on the site of development of endogenous stages, the reaction of host cells to parasite development and common oocyst morphology (shape, presence/absence of a Stieda body and exogenous/ endogenous sporulation). This form of classification has not been widely accepted and is not used in the current paper. However, should the criteria proposed by Paperna and Landsberg (1989) become recognised as sufficient for the designation of new genera and knowledge of the endogenous development of $E$. foulshami become available, its generic classification should be re-assessed. The cylindroidal-ellipsoidal oocysts of the following Eimeria species are the same width or wider than E. foulshami, but all are longer: Eimeria urosauris Bovee, 1966 (SI, 1.6) from Urosaurus graciosus in California (Bovee 1966); Eimeria umis Bovee, 1969 (SI, 1.86) from Uma notata 
in California (Bovee 1969); Eimeria basilisci Duszynski, 1969 (SI, 2.14) from Basiliscus basiliscus in Costa Rica (Duszynski 1969); Eimeria ahtanumensis Clark, 1970 (SI, 1.73) from Sceloporus occidentalis in Central Washington State, USA (Clark 1970); and Eimeria anolidis Daszak et Ball, 1991 (SI, 1.96) from Anolis carolinensis in Florida (Daszak and Ball 1991). The only cylindroidal eimerian from the family Cordylidae, Eimeria murphyi Upton, McAllister et Garrett, 1993 from Cordylus cataphractus is much larger, truly cylindroidal (SI, 2.07) and possesses a polar granule (Upton et al. 1993).

Caryospora regentensis. Five species of Caryospora have been previously described from snakes of the family Elapidae. Of these, Caryospora constanciae Lainson, Paiva do Nascimento et Shaw, 1991 from Micrurus spixii spixii in Brazil (Lainson et al. 1991) and Caryospora demansiae Cannon, 1967 from Demansia psammophis in Australia (Cannon 1967) are significantly larger with no overlap in oocyst or sporocyst ranges for the former. The presence of small darkbrown tubercles on the outer wall, predominant lack of polar granules and smaller sporocyst residuum further distinguishes $C$. demansiae from C. regentensis. Caryospora cobrae Nandi, 1985 from Naja naja in India (Nandi 1985) is larger with a distinct micropyle and without a polar granule. Oocysts of Caryospora najae Matuschka, 1982 from Naja nigricollis pallida in East Africa (Matuschka 1982) lack a polar granule, are markedly smaller than and overlap only slightly in size ranges with oocysts of $C$. regentensis. The sporocysts of C. najae also are smaller and contain a more scattered residuum consisting of less granules than those of $C$. regentensis. Both oocysts and sporocysts of Caryospora micruri Lainson, Paiva do Nascimento et Shaw, 1991 from Micrurus spixii spixii in Brazil (Lainson et al. 1991) overlap in size ranges with $C$. regentensis; however, the sporocyst residuum of $C$. micruri is less noticeable, consisting of smaller granules scattered loosely within the sporocyst. These morphological differences, combined with the geographical isolation and evolutionary distance between these hosts suggest that the two species are distinct.

Caryospora legeri Hoare, 1933. The oocysts described in the current paper are larger than the type, described from a Psammophis s. sibilans from Entebbe, Uganda (Hoare 1933); however, oocyst length ranges overlap although width ranges do not by $1.4 \mu \mathrm{m}$. Sporocyst width ranges overlap, but length ranges do not by $1.5 \mu \mathrm{m}$. The morphology of oocysts and sporocysts is identical between the two isolates. The only other difference is that Hoare (1933) reports a "minute funnel-shaped micropyle" which "can sometimes be made out" in C. legeri oocysts. The lack of this feature (which may simply be an erroneously identified polar granule attached to the oocyst wall) in another isolate from the same host species is almost certainly not of enough significance to warrant designation of a separate species. For this reason and because there are overlaps in dimensions of both oocyst and sporocyst, we conclude that the species reported in the current paper is C. legeri and represents a new geographic record for the species.

Caryospora legeri Hoare, 1933. Syn.: Caryospora psammophi Bray, 1960; Caryospora hermae Bray, 1960. We propose that C. psammophi and C. hermae should be considered junior synonyms of $C$. legeri. The oocysts described for C. psammophi and C. hermae from Psammophis sibilans phillipsi from Liberia, west Africa are insufficiently distinct from each other and from those of C. legeri Hoare, 1933 from P. s. sibilans to warrant separate specific status.

Caryospora psammophi: Oocysts of this species were originally described from the faeces of a Liberian Psammophis sibilans phillipsi, a western subspecies of the type host of $C$. legeri. The only differences between C. psammophi and C. legeri are size (which overlap significantly for length and width of both oocyst and sporocyst) and the lack of the micropyle (possibly a misidentified polar granule attached to the oocyst wall) reported in some oocysts of C. legeri (Hoare 1933, Bray 1960). It is unclear whether oocysts of C. psammophi possess a substieda body since although Bray (1960) does not state whether one is present or absent, his drawing shows an oocyst without a substieda, in contrast to those of C. legeri (Hoare 1933). However, substieda bodies were difficult to distinguish in many of the oocysts of $C$. legeri examined in the current study, suggesting that these differences are also probably insufficient to warrant separate specific status. Endogenous stages also showed no significant morphological differences from $C$. legeri. In their review of the genus Caryospora, Upton et al. (1986) suggested that $C$. psammophi "may, in time, prove to be a synonym of $C$. legeri" and commented that the two differ in the presence of a small, dubious micropyle. Measurement ranges of oocysts and sporocysts for the type $C$. legeri and C. psammophi overlap, as do ranges for $C$. psammophi and the oocysts reported as C. legeri in the current paper. We therefore propose that $C$. psammophi is a junior synonym of $C$. legeri Hoare, 1933.

Caryospora hermae: Bray himself noted that the oocysts of his $C$. hermae only differed from $C$. (psammophi) legeri in size and from the type of $C$. legeri in size, lack of a micropyle, smaller amount of sporocyst residuum and an oval schizont (Bray 1960). Of these criteria, none appear to be valid. Firstly, the length and width ranges for both oocysts and sporocysts of $C$. hermae and C. legeri overlap. Secondly, the micropyle of $C$. legeri is only present on some oocysts. Thirdly, the amount of sporocyst residuum appears to be similar between the two species and finally, 
schizonts of both species are oval in longitudinal section and, since the shape of endogenous stages of coccidia may vary, are not a valid criterion for distinguishing species. Thus we propose that $C$. hermae is a junior synonym of $C$. legeri. This brings the total number of Caryospora species found in P. sibilans to two: C. legeri Hoare, 1933 from Psammophis sibilans sibilans and C. weyerae Bray, 1960 from P. sibilans phillipsi.

Eimeria samyadeli Iskander et Tadros, 1979 emend. Eimeria samiae Iskander et Tadros, 1979 was described from the intestinal contents and gall bladder of an Indonesian species of python, Python "reticulata" (Serpentes: Pythonidae), which died at Giza Zoo, Egypt. The senior author named the species after his son, Samy Adel Iskander and incorrectly used the feminine gender. The specific name should have read "samyi" to reflect the gender of the person honoured. However, emending to the correct gender may cause confusion with Eimeria sami described by Bovee (1971) from the scincid lizard Eumeces oshimensis of Amami Island, Japan and named in honour of Dr. Sam R. Telford. We have avoided this problem and conformed to the original aim of honouring the senior author's son by emending the specific name to the masculine genitive of Samy Adel: samyadeli. In addition to this correction, the specific name of the host was misspelled and should be corrected to Python reticulatus Schneider, 1801. A further potential problem exists with the original description of E. samyadeli. It is not possible to discern either sporocyst walls or sporozoites in the photomicrographs published by Iskander and Tadros (1979) and the lack of detail in the drawings makes it impossible to confirm that the species is an eimerian. Furthermore, the author's description of the sporocyst as "banana-like" and containing "two sporozoites which occur near its two extremities, leaving a small vacant place in its middle" is unusual. Oocysts of a number of Eimeria spp. of snakes have been described which contain very elongate sporocysts (Upton and McAllister 1990, Upton et al. 1992) and it may be that sporocysts of E. samyadeli are similar in appearance. However, it seems likely that a re-examination of this species would be useful and might allow a more detailed description.

Unidentified Eimeria sp. The only eimerians reported from the Chamaeleonidae with spherical or subspherical oocysts are an unidentified species recovered from the gallbladder and intestinal tract, respectively, of seven Chamaeleo spp. in Madagascar (Brygoo 1963) and Eimeria vencesi and Eimeria worthi from Madagascan chameleons (Modrý et al. 2001). It is clear that Brygoo (1963) considered all samples of the spherical species conspecific and he therefore gave measurements for those from Chamaeleo oustaleti (25-26 oocyst diameter) and drew those from Chamaeleo brevicornis (19.7 oocyst diameter, 8.8 sporocyst diameter, measured from drawing). The spherical oocysts reported from Chamaeleo dilepis in the current paper are smaller than those reported from $C$. oustaleti and larger than those from $C$. brevicornis (Brygoo 1963). The two species found in Madagascan chameleons by Modrý et al. (2001) have smaller oocysts which do not overlap in range with the unidentified eimerian presented here. All other coccidia reported from chameleons are eimerians with cylindroidal oocysts (Modrý et al. 2000) or isosporans (Sergent 1902, Modrý and Koudela 1995, Modrý et al. 2000). These data and the geographical and evolutionary distance between the Malagasy and African mainland chameleons suggest that the spherical Eimeria species reported in the current paper from $C$. dilepis is probably new and if further specimens become available, should be described as such.

Acknowledgements. We are indebted to Dr. David Modrý (University of Veterinary and Pharmaceutical Sciences, Brno, Czech Republic) for allowing us access to unpublished data. We are grateful to the following staff of the Zoological Society of London (ZSL), Regent's Park, London, UK: Simon Tonge (former head curator) and Dr. James K. Kirkwood (former head, Veterinary Science group, Institute of Zoology - IOZ) for permission to collect specimens; David Risley, Esther Wenman, Matthew Fagg and Terry March (Reptile Department) for assistance with collection and tracing the history of captive animals; A.A. Cunningham (IOZ) for advice on veterinary matters; Shaheed McGregor and Martine Carole (IOZ) for laboratory assistance. John Foden of Drayton Manor Park kindly advised on aspects of mamba biology. We would like to thank Simon King of "King's Reptile World", Camden, London, UK; Peter Foulsham and Stewart Worth of "Eurorep" (formerly "British Herpetological Supply"), Hayes, Middlesex, UK and Bradley Whinfield, "The Vivarium", Walthamstow, UK for kindly allowing access to captive Gerrhosaurus major.

\section{REFERENCES}

AMOUDI M.A. 1989: Two new species of Isospora from the desert skink (Chalcides ocellatus) from the Egyptian desert. J. Protozool. 36: 237-238.

BOVEE E.C. 1966: Eimeria urosauris sp. n., a coccidium from the lizard Urosaurus graciosus Hollowell, in California. J. Protozool. 13: 607-610.
BOVEE E.C. 1969: Eimeria umis sp. n., a coccidian parasite from the lizard Uma notata Baird. Trans. Am. Microsc. Soc. 88: 257-265.

BOVEE E.C. 1971: New species of Eimeria from lizards of Japan. Trans. Am. Microsc. Soc. 90: 336-343. 
BRAY R.S. 1960: On the parasitic protozoa of Liberia. III. Three new species of Caryospora Léger, 1904 from the hissing sand snake Psammophis sibilans phillipsi and a note on a Caryospora in Coluber ravergieri nummifer from Israel. J. Protozool. 7: 314-320.

BROADLEY D.G. 1987: A review of geographical variation in Gerrhosaurus major Duméril (Sauria: Cordylidae). Herpetol. J. 1: 194-198.

BRYGOO E.R. 1963: Contribution à la connaissance de la parasitologie des caméléons malgaches. Ann. Parasitol. Hum. Comp. 38: 525-739.

CANNON L.R.G. 1967: Caryospora demansiae sp. n. (Sporozoa: Eimeriidae) from an Australian snake Demansia psammophis (Elapidae). Parasitology 57: 221-226.

CLARK G.W. 1970: Eimeria ahtanumensis sp. n. from the Northwestern fence lizard Sceloporus occidentalis in Central Washington. J. Protozool. 17: 526-530.

DASZAK P., BALL S.J. 1991: Five new species of Eimeria (Apicomplexa: Eimeriidae) from lizards. Syst. Parasitol. 20: 141-147.

DUSZYNSKI D.W. 1969: Two new coccidia (Protozoa: Eimeriidae) from Costa Rican lizards with a review of the Eimeria from lizards. J. Protozool. 16: 581-585.

HOARE C.A. 1933: Studies on some new ophidian and avian coccidia from Uganda, with a revision of the classification of the Eimeriidea. Parasitology 25: 359-388.

ISKANDER A.R., TADROS G. 1979: Eimeria samiae sp. nov. (Eimeriidae: Sporozoa) from the snake Python reticulata and its pathogenicity in the intestine. Bull. Zool. Egypt 29: 66-71.

LAINSON R., PAIVA do NASCIMENTO F., SHAW J.J. 1991: Some new species of Caryospora (Apicomplexa: Eimeriidae) from Brazilian snakes, and a re-description of C. jaracarae Carini, 1939. Mem. Inst. Oswaldo Cruz 86: 349-364.

MATUSCHKA F.-R. 1982: Caryospora najae sp. $\mathrm{n}$ (Apicomplexa: Eimeriidae) from the spitting cobra, Naja nigricollis pallida (Serpentes: Elapidae). J. Parasitol. 68: 1149-1153.

MODRÝ D., DASZAK P., VOLF J., VESELÝ M., BALL S.J., KOUDELA B. 2001: Five new species of coccidia (Apicomplexa: Eimeriidae) from Madagascan chameleons (Sauria: Chamaeleonidae). Syst. Parasitol. 48: 117-123.
MODRÝ D., KOUDELA B. 1995: Description of Isospora jaracimrmani sp. n. (Apicomplexa: Eimeriidae) from the Yemen chameleon Chamaeleo calyptratus (Sauria: Chamaeleonidae). Folia Parasitol. 42: 313-316.

MODRÝ D., KOUDELA B., VOLF J. 1997: Four new species of Isospora (Apicomplexa: Eimeriidae) from reptiles from the islands of Seychelles. Syst. Parasitol. 37: 73-78.

MODRÝ D., ŠLAPETA J.R., KOUDELA B. 2000: Six new species of coccidia (Apicomplexa: Eimeriidae) from East African chameleons (Sauria: Chamaeleonidae). J. Parasitol. 86: 373-379.

NANDI R. 1985: Caryospora cobrae n. sp. from the Indian cobra Naja naja Linnaeus. J. Protozool. 32: 204-205.

PAPERNA I., LANDSBERG J.H. 1989: Description and taxonomic discussion of eimerian coccidia from African and Levantine geckoes. S. Afr. J. Zool. 24: 345-355.

SERGENT M.E. 1902: Sur une coccidie nouvelle, parasite du cameleon vulgaire. C. R. Soc. Biol. (Paris) 54: 1260-1261.

UPTON S.J., CURRENT W.L., BARNARD S.M. 1986: A review of the genus Caryospora Léger, 1904 (Apicomplexa: Eimeriidae). Syst. Parasitol. 8: 3-21.

UPTON S.J., FREED P.S., BURDICK D.A. 1992: Description of the oocysts of three new species of coccidia (Apicomplexa: Eimeriidae) from lizards in Namibia. Syst. Parasitol. 22: 33-37.

UPTON S.J., FREED P.S., BURDICK D.A., McALLISTER C.T. 1990: Seven new species of coccidia (Apicomplexa: Eimeriorina) from reptiles in Madagascar. Can. J. Zool. 68: 2368-2375.

UPTON S.J., McALLISTER C.T. 1990: The Eimeria (Apicomplexa: Eimeriidae) of Serpentes, with descriptions of three new species from colubrid snakes. Can. J. Zool. 68: 855-864.

UPTON S.J., McALLISTER C.T., GARRETT C.M. 1993: A new species of Eimeria (Apicomplexa) from Cordylus cataphractus (Sauria: Cordylidae), from South Africa. J. Egypt. Soc. Parasitol. 23: 189-194.

UPTON S.J., McALLISTER C.T., TRAUTH S.E. 1992: Description of the oocysts of two new species of Eimeria (Apicomplexa: Eimeriidae) from the rough earth snake Virginia striatula (Serpentes: Colubridae) in Texas and Arkansas. Syst. Parasitol. 23: 51-54. 